\title{
NEW DEVELOPMENTS IN WATER POLLUTION LAW AND POLICY IN CHINA: EFFECTIVE ENOUGH TO COPE WITH WATER POLLUTION CONFLICT?
}

\author{
Du Qun \\ Professor and Deputy Director, Research Institute of Environmental Law, \\ Wuhan University, People's Republic of China
}

\begin{abstract}
Water pollution is one of the most serious environmental issues facing China. In 2005, an exceptionally serious water pollution accident in the Songhua River - caused by an unintended and sudden chemicals explosion - heralded an official recognition of a water pollution crisis in China. Although there have been new initiatives in national law and policy concerning water pollution that attempt to respond to issues of: social conflict caused by water pollution; government accountability; liability of polluting entities; and citizens' rights in cases of water pollution, the challenges for the rule of environmental law in effectively reducing water pollution accidents and resolving water pollution conflict still exist. There is an urgent need to strengthen compliance and enforcement. This paper discusses the issues of water pollution conflict and the possible resolutions offered through law and policy.
\end{abstract}

\section{Introduction}

Water pollution is one of the most serious environmental issues facing China. In 2005, an exceptionally serious water pollution accident in the Songhua River - caused by an unintended and sudden chemical explosion - heralded the commencement of attention to the water pollution crisis in China.

According to The China Environment Bulletin, 2009, issued by the Ministry of Environmental Protection ('MEP') in June 2010, over 42 per cent of the water bodies of rivers were severely polluted, with water quality ranked at polluted classes (IV, $\mathrm{V}$ and below $\left.\mathrm{V}^{1}\right) .{ }^{2}$ Of all the rivers in the country, China invests the most in the Huai River to control pollution, but in spite of such investment, the severity of its pollution remains unchanged. Many species of fish which lived in the river ten years ago now no longer exist. The lakes connected to the river have also become polluted. In Wuhan, the capital city of Hubei Province, the water quality of most urban lakes is in the 'polluted' class (Classes IV and V). ${ }^{3}$ Bad water quality is affected by cost effective industrial planning. A 2006 survey on environmental risk conducted by the State Environmental Protection Administration, ${ }^{4}$ showed that 81 per cent of the 7,555 large-scale heavy chemical industry projects were located in watersheds and highly populated areas, 45 per cent of these were classified as sources of high risk. ${ }^{5}$

\footnotetext{
1 The national environmental quality standards for surface water (2002) are divided into five categories of water bodies, based on their intended water use and conservation goals: Class I for the water source and the water in the State Nature Reserve; Class II for drinking water sources in Class I Protected Areas, rare fish and aquatic habitat protection areas, fish and shrimp spawning grounds, etc; Class III for drinking water sources in Class II Protected Areas, fish and shrimp winter grounds, migration channels, such as aquaculture, fishing water and swimming areas; Class IV for general industrial water areas and entertainment areas where water does not directly touch human bodies; Class V primarily for agricultural use and landscape viewing.

2 Ministry of Environmental Protection ('MEP'), 'The State of China's Environment: Freshwater' (2009) The China Environment Bulletin <http://jcs.mep.gov.cn/hjzl/zkgb/2009hjzkgb/201006/t20100603_190435.htm>.

3 The Environment Protection Department of Hubei Province, An Urge for Water Treatment in Wuhan (2008) <http://www.hhepb.gov.cn/hbdt/hjxw/200810/t2008101_5928.html>.

${ }^{4}$ The State Environmental Protection Administration ('SEPA') became the MEP in 2008.

5 SEPA, The Final Report of the Investigation of the Environmental Management Risk of Chemical Industry in China (2006)<http://old.jfdaily.com/gb/node2/node142/node200/userobject1ai1399439.html>.
} 
The problems arising from bad water quality and water pollution are obvious; they affect both drinking water and agriculture. About 320 million rural people (about one quarter of China's population) do not have access to potable water. The polluted water of rivers and lakes are used for agricultural irrigation and cause large-scale soil contamination, and poor crop quality and yield. In recent years, there have been increasing cases of people, including many teenagers, who have been affected by heavy metals and other toxic substances caused by the use of contaminated water. ${ }^{6}$

Since 2005, social conflict caused by water pollution has increased because of the frequency of large water pollution accidents. According to articles in The China Environment Bulletin in 2007, 2008 and 2009, there were 34, 74 and 80 large water pollution emergency cases reported and handled respectively in those years. ${ }^{7}$ Because culpable enterprises often fail to take responsibility for compensating victims of pollution incidents and restoring damaged environments, the social conflict caused by water pollution is becoming an increasingly significant issue for the whole society.

No doubt social conflict over water pollution is a consequence of the interaction between social, economic, technological and environmental factors. There are many possible reasons why water conflict exists and persists, but there are also many possible resolutions. This paper discusses the issues embedded in water pollution conflict in China and the resolutions being explored through law and policy.

\section{Water pollution conflict and the ineffectiveness of water law}

Given the frequency of water pollution accidents and the consequent disputes, it is reasonable to ask whether environmental law and the existing command-control system for dealing with water pollution control in China can work. Responding to this question requires some background information about China's law and regulatory regime for water quality control.

In China, the national law that deals with water pollution is the Law for Prevention and Control for Water Pollution ('LPCWP'). It was introduced in 1984, revised in 1996, with the latest revision in 2008. ${ }^{8}$ Other national laws, such as the Environmental Impact Assessment Law 2002, ${ }^{9}$ are also used to regulate water pollution issues.

Water pollution conflict in China is, to some extent, a reflection of the ineffectiveness of LPCWP 1984 , and other laws and policies concerning water quality control. The causes of ineffectiveness are threefold: weak accountability of the people's government; disregard for social responsibility by polluters (mainly enterprises); and indifference to the environmental rights of citizens to water. Each of these issues will now be examined in more detail.

\footnotetext{
A number of 'cancer villages' (the suspected cause of cancer being environmental pollution) have been reported in the last five years. One report told the story of a retired geologist, Lin Jin-xing, who dedicated himself to finding the cause of cancer in the village of Longling in Shaanxi Province. He collected and analysed samples of soil, water, crops and other materials that might contain cancer-causing substances. He concluded that the toxic discharge from a fertilizer factory situated five kilometers from the village into the waters and air in the region was causing pollution of soil, water and most of the crops that the villages depend upon. The Lin case was taken up by Premier Wen Jiabao who requested local leaders to take corrective measures. However no substantive action was taken and most villagers have now abandoned the land. Other stories of 'cancer villages' are available on the CCTV Discovery website (for example stories about: Shangba Village in Wenyuan County of Guangdong Province, 2001; several cancer villages in Shenqiu County of Henan Province, 2004; and Quwan Village in Xiangfan City of Hubei Province, 2005).

${ }^{7}$ The total number of large environmental emergency cases in 2007, 2008 and 2009 were 108, 135 and 171 respectively. See China Environment Bulletin 2007/2008/2009), Chinese text can be retrieved at <http://wenku.baidu.com>.

${ }^{8}$ Law of the People's Republic of China on Prevention and Control of Water Pollution (LPCWP) 2008, Standing Committee of National People's Congress, Order No 87, 28 February 2008.

<http://edu. westlawchina.com/maf/china/app/document?\&src=nr\&docguid=i3cf76ad30000011ef3546d026343198c\&lan $\mathrm{g}=$ bi\&crumb-action=append\&crumb-label $=$ 文件 $>$.

9 Environmental Impact Assessment Law 2002, Standing Committee of National People's Congress, Order No 77, 28 October 2002 <http: www.gov.cn/gongbao/content/2002/content61822.htm>.
} 


\section{Weak accountability of governments}

Governments are key actors in China's water quality governance. They are responsible for setting overall pollution targets and pollution discharge standards. They are also empowered to formulate water pollution control policies and to use public financial resources to prevent and treat pollution. In addition, governments and their environmental protection departments have the power to enforce environmental law. In recent years, the effectiveness of governments' performance in water pollution control has been questioned. The China Environment Bulletin 2005 reported that the targets for the control of major pollutants stated in the Chinese Government's 10th Five-Year Plan period (2001-2005) for national environmental protection objectives, have not been achieved. ${ }^{10}$ One of the non-achieved targets concerning water pollution, the indicator of Chemical Oxygen Demand ('COD') discharges, did not decrease but showed an increase of two per cent. ${ }^{11}$ This news item was the first time the Chinese central government raised the issue of the need for governmental accountability to fulfil environmental protection targets and tasks. ${ }^{12}$ The item initiated much legal discussion on how environment law could be improved. As a result of this consideration, the $11^{\text {th }}$ Five Year Plan (2006-2010) introduced compulsory targets to address governmental accountability.

The difficulty faced by local people's governments was how to balance economic growth, and social and environmental development with water pollution control. Under the current pattern of economic development, governments themselves are stakeholders in economic growth. They share a significant proportion of economic gain from the business activities of enterprises causing water pollution. This benefit-sharing mechanism between governments and polluters inhibits the desire of either party to comply with environmental law. When GDP growth becomes the overwhelming objective of regional development all around the country, many enterprises and their managers, and many officials and political leaders still believe that 'pollution first, treatment later' is the inevitable way for the country to prosper.

The pursuit of economic prosperity with a disregard for environmental protection has led to the setting of ineffective economic incentives to comply with environmental law. For example, the fee set for polluted discharge and the penalty for violations of environmental law are significantly less than the costs to remedy citizens' actual losses and to recover water function. To save on the cost of transportation and disposal of industrial waste, governments continue the now out-dated - practice of allowing construction of heavy industrial factories along the banks of large rivers and lakes in populated areas and near the origin of water sources. Over 60 per cent of large and medium-sized chemical factories are located along the banks of the Yellow and Yangtze Rivers; in addition there are numerous small papermaking factories and tannery plants. Critics describe such industrial setting as 'chemicals surround cities'.$^{13}$ Remedying the situation calls for the need to improve governmental accountability in environmental and social safety prior to economic development.

Although factories account for a significant amount of pollution, lack of sewerage infrastructure is also a significant factor. Over 58 per cent of Chinese cities have no sewage treatment infrastructure. Sewage treatment construction in the countryside, particularly in small towns which are becoming increasingly populated, has not yet begun. In cities that have sewage treatment facilities, many are not well maintained to save costs. ${ }^{14}$

\footnotetext{
10 SEPA, The China Environmental Bulletin (2005) <http://www.zhb.gov.cn/plan/zkgb/05hjgb>.

${ }^{11}$ Environmental Planning Academy of China, Analysis of Implementation of the Eleventh Five-Year National Environmental Protection Planning Targets (2006) <http://www.chinanews.com.cn/news/2006/2006-0412/8/715966.shtml>.

${ }^{12}$ The $11^{\text {th }}$ Five Year Plan consequently introduced 'obligatory targets'.

${ }^{13} \mathrm{X}$ Wu, 'Who secures the Safety from Chemical Industry', China News Net (online), 18 August 2010 <http://news.xinmin.cn/rollnews/2010/08/18/6367325.html>.

${ }^{14}$ Chou Baoxing, the Vice Minister of Ministry of Housing and Urban-Rural Development, announced, at the 5th International Congress on Water Service Development in China for Cities and Towns, $10^{\text {th }}$ November, that in the next five years 2011-15, China will invest 150 billion yuan in developing sewage service facilities, in particular in small cities and towns. B Chou, 'The Speech to the $5^{\text {th }}$ International Congress on Water Service Development in China for Cities and
} 


\section{The liability of polluters}

Water polluter liability in Chinese law is fairly strict. The LPCWP has many principles and instruments that theoretically regulate polluters' activities. Measures such as: the need to conduct environmental impact assessments ('EIA'); pollutant discharge control (for example polluters reporting and registering to the authority on the quality and exact location of pollutant discharge, the standard of pollutant discharge and treatment); polluter pays (including the fee and the penalty for pollutant discharge), time-limited treatment orders, removal of old production processes and facilities. However these command-control measures have not effectively deterred entities from polluting water. ${ }^{15}$

A fundamental cause for failure of the LPCWP measures is the varying interpretations of the polluter-pays liability. As already mentioned, fees and penalties for polluting beyond allowable discharge levels are very low, providing little incentive to comply. In addition, small and medium-sized enterprises sometimes take illicit means to avoid payment of pollution discharge fees by laying covered conduits to discharge pollutants directly into water bodies, thereby avoiding detection of discharge by the environmental protection authority.

\section{The water quality right of citizens}

The right to clean water is fundamental to a citizens' right to health and should be upheld by Chinese law. But, as will be discussed below, Chinese civil law has traditionally advocated fault liability in pollution torts that are contradictory to environmental legislation. Consequently, courts have not upheld strict liability and have maintained a regime of victims' burden of proof. The way that pollution torts law works and the other general obstacles to citizens' access to justice have further exacerbated disputes and conflicts caused by water pollution.

\section{Review of newly developed legislation and policy concerning water pollution conflicts}

Since 2005, much legislative and policy efforts have been carried out to address water pollution issues in China. The most influential efforts have been: the 2008 revision to LPCWP; the new Torts Liability Law 2009; ${ }^{16}$ and other corresponding water pollution policies being piloted at a national or local scale.

\section{LPCWP 2008}

The LPCWP was formulated in 1984, and amended in 1996 with an aim to consolidate the supervisory power of the responsible authority to combat water pollution. However LPCWP 1996 was criticised as still too weak. In 2008, a second revision of the LPCWP was completed by the $32^{\text {nd }}$ Session of the Standing Committee of the Tenth National People's Congress. The revision extended the legislation's scope of water pollution activities. LPCWP 2008 includes 30 more articles that cover the issues of: protecting drinking water (10 arts in Chapter 5); ${ }^{17}$ enhancing

Towns', Hong Kong Commercial Daily, 10 November 2010. This paper will use Chinese yuan as the currency measurement. The ratio of American dollar to Chinese yuan is approximately 6:5.

${ }^{15}$ See Explanation Document on the Revision Draft of the Law for Prevention and Control for Water Pollution 1996 provided by the Minister of the Ministry of Environmental Protection and presented to the Standing Committee of National People's Congress for reading and approval in 2007. Paragraph 8 of the Explanation Document is relevant. For the Chinese text of the Explanation Document, see <http://www.npc.gov.cn/npc/zt/2008-

05/20/content_1494738.htm>.

${ }^{16}$ Torts Liability Law 2009, National People's congress, Order No 21, 26 December 2009 <http://ww.gov.cn/flfg/200912/26/content_1498435.htm>.

${ }^{17}$ The articles with new elements to enhance governmental accountabilities exist in arts 5, 7, 18, 20, 74 and 75, and arts $9,69,72,74,75,76,80,82$ and 83 are for enterprises' liabilities. 
governments' accountabilities and enterprises' liability; ${ }^{18}$ and improving mechanisms for citizens' participation in water pollution control and access to justice.

\section{Protecting drinking water sources}

Almost all water pollution disputes and accidents concern drinking water and the health of people. The Shaoguan Smelting Plant's illegal discharge of cadmium in 2005 and the Sichuan Chemical Co's waste leaks into the Tuojiang River in 2006 - together listed as the worst accidents and pollution in 2005-2008, brought about large-scale drinking water crises. The affected waters remain polluted, causing problems for both the local people and government. From the legal perspective, these situations occurred because LPCWP 1996 did not provide enough emphasis on the value of protecting drinking water; it only provided very general prohibitive rules for the establishment of drinking water source protection zones ('DWSPZ'). Article 1 of LPCWP 2008 established the importance of protecting drinking water sources and art 3 established the legal principle for overall water pollution control.

Moreover, LPCWP 2008 has a chapter and specific measures for protecting drinking water sources and special water bodies. The system of DWSPZ that LPCWP 1996 generally introduced is reaffirmed and improved in LPCWP 2008, and, in addition, LPCWP 2008 adds a grading system for DWSPZ. There are two formal grades of DWSPZ (with different restrictive measures) plus a less formal quasi-protection zone for certain areas outside the DWSPZ when necessary:

- Within the first-grade DWSPZ, all new construction, reconstruction or expansion of construction projects that threaten water supply facilities and protection of water sources within drinking water source protection zones is prohibited; the conduct of cage aquaculture, touring, swimming, angling or other activities that may pollute drinking water bodies is prohibited (art 58).

- Within the second-grade DWSPZ, new construction, reconstruction or expansion of construction projects that discharge pollutants is prohibited; the conduct of cage aquaculture, touring or other activities are allowed but are pursuant to provisions to prevent the pollution of drinking water bodies (art 59).

- Within drinking water source quasi-protection zones, new construction or expansion of construction projects that seriously pollute water bodies is prohibited, and the reconstruction of projects must not result in an increase of discharge volume. In the case where the contamination of a drinking water source occurs that threatens the safety of a water supply, the environmental protection department must order the enterprises or institutions concerned to take measures to stop or reduce the discharge of pollutants (art 60).

- The State Council and the people's governments of provinces, autonomous regions and municipalities directly under the Central Government may stipulate and adopt measures to forbid or limit the use of phosphonium-bearing abstergents, chemical fertilisers and pesticides, and limit cropping and breeding within drinking water source protection zones according to the need for protection of the marine environment (art 61).

- Along with the prohibitions and restrictions set for DWSPZ, LPCWP 2008 stipulates liabilities for violation of the above-mentioned rules. In general, the setting-up of sewage outlets within DWSPZ is prohibited (art 57). If an entity sets up sewage outlets in the protected zones, it may be ordered to dismantle or close down the outlet within a prescribed time limit and be fined between 100000 and 1000000 yuan (art 75).

The chapter dealing with zones also defines the responsibilities of the authority and its powers to set up or adjust DWSPZ; only the people's governments of provinces, autonomous regions or municipalities responsible to the Central Government have power to approve the plan and report with regard to the division of DWSPZ.

${ }^{18}$ The new articles for citizen rights regarding water pollution control exist mainly in arts 10, 19, 25, 87 and 88 . 
Approval authorities and the State Council have power to intervene to adjust the scope of zones based on the actual need for the protection of drinking water resources. These centralised measures have been introduced to attempt to overcome lower level governments adjusting zone boundaries. The relevant local people's governments must set up clear geographical landmarks and conspicuous warning signs on the boundaries of DWSPZ (art 56)

An issue that remained unclear in LPCWP 2008 was whether existing facilities located within DWSPZ would have to abide by the new regulations. Obviously, it is not enough if the new provisions on DWSPZ are only imposed on newly established entities.

\section{Intensifying accountabilities of governments}

LPCWP 1996 required local governments at all local levels to take responsibility for both the formulation and execution of water pollutant discharge standards, and prevention and control plans for water pollution. With regard to water disputes resulting from trans-boundary water pollution, it was the responsibility of local governments to arrive at a resolution that involved all stakeholders. However the provisions of LPCWP 1996 were not effectively implemented. The approach of 'pollution to achieve development' - or 'pollution first treatment later' - tended to be the dominant philosophy in most regions. In order to force local governments to carry out development in an ecologically sustainable manner, LPCWP 2008 created a series of legal instruments to address governmental accountabilities:

\section{1. 'Governmental responsibility system' and 'Assessment and appraisal system'}

An assessment and appraisal system makes the achievement of certain targets for protecting water bodies compulsory. Meeting targets will be taken into consideration in appraising whether local people's governments and their responsible persons perform appropriately and effectively in their governing period (art 5). Strictly speaking, the 'responsibility system' and the 'assessment and appraisal system' is not a legal approach but is capable of introducing political sanctions. LPCWP 2008 is the first legislation to introduce political sanctions. There is some debate about whether the measure will work. Some commentators believe the measure will increase the will of local governments to take responsibility for water quality protection within their jurisdiction. ${ }^{19}$ Other commentators argue that political sanctions should not have primacy over legal force. ${ }^{20}$

\section{Total discharge control of major pollutants}

Pollutant discharge control is one of the basic legal instruments to protect water quality. The conventional method in China was to use national or local standards that limited the concentration proportion of prescribed polluting substances for discharge into water bodies. The problem was that the concentration set often exceeded the natural load capacity of the waterway because total discharge from all polluters was not considered. LPCWP 2008 introduced tighter controls by requiring that total discharge in very polluted water bodies needed to meet the national standard (art 16).

Because degradation of water bodies continued to occur even with the measures introduced in LPCWP 1996, LPCWP 2008 extended the application of the total discharge limit of major pollutants to all water bodies. Article 18 empowers the people's governments of provinces, autonomous regions and municipalities which are directly under the Central Government to examine what receiving waters can accept then allocate allowable rates (sub control targets) to the people's governments of cities and counties. The people's governments of cities and counties are then required to ensure that discharges meet the standards set.

\footnotetext{
${ }^{19} \mathrm{~T}$ Bie, 'Analysis on the progress of the new law for the prevention and control of water pollution' (2008) 3 The Journal of Environmental Protection 40.

${ }^{20}$ Professor Wang Jin at Peking University made such comments on the removal of local leaders and other means to resolving legal issues in the Zijin pollution accident.
} 
LPCWP 2008 (art 18) requires that even the pre-2008 developments that have received approval to discharge at levels above those set after 2008 must comply: the environment protection department of the relevant people's government is required to suspend review of the EIA documents of enterprises that will increase discharge beyond allowable limits. In fact, the practice of suspending the review of EIA in the region where major pollutants exceeded the limit of total discharge began as a temporary measure in 2007 when Tangshan City in Hubei Province, Luliang City in Shanxi Province, Liupanshui City in Guizhou Province and Laiwu City in Shangdong were ordered to suspend development and construction. LPCWP 2008 has brought this temporary practice into the permanent regulatory regime.

This LPCWP 2008 measure of controlling total discharge promises to be an important tool in alleviating the conflict between water protection, and economic development and construction.

\section{Pollution discharge permits system}

LPCWP 1996 required polluting entities to report: type of pollutants, discharge quantity and treatment facilities to relevant environmental protection departments. It also required enterprises to have treatment facilities. However LPCWP 1996 had a significant loophole. It created two levels of fees: one for discharge within the legal standards; and one for discharge above the legal standard. The existence of the second fee implied that discharge above the legal discharge level was also legal and encouraged enterprises to disregard requirements for treatment facilities.

LPCWP 2008 abolished the second discharge fee and established that violations of legal discharge standards are subject to a penalty. In addition, LPCWP 2008 adopted a permit system for pollution discharge: all entities wishing to discharge into waterways are required to obtain a permit from the relevant environment protection department. The permit prescribes conditions for discharge as stipulated in LPCWP 2008. The pollutant discharge permit system enables more accurate accounting for discharges by authorities, it also utilises a market mechanism by enabling the trading of permits. $^{21}$

\section{Supervision and enforcement power for the prevention of water pollution}

Water pollution accidents are typical examples of the ineffectiveness of past water pollution routine supervision and enforcement controls. LPCWP 2008 enhances supervisory powers in a number of ways:

\section{Decentralised and increased power to order waste treatment within a prescribed time limit}

Under LPCWP 1996, the environmental protection department had the power to propose that a violating entity be ordered to cease its activity but it was individual people's governments who were charged with the execution of the order. LPCWP 2008 endows the environmental protection authority with direct power to order entities for water treatment to stop any illegal discharge by a prescribed time. This is an important decentralisation of executive power from the people's government to the environmental protection authority. Article 74 contains two relevant paragraphs: the first paragraph concerning this power shift reads:

[If] any entity, in violation of the provisions of this Law, discharges water pollutants exceeding the national or local standards for discharging water pollutants or exceeding control

\footnotetext{
${ }^{21}$ A pilot program, 'compensated use and trading of discharge permit' ('CUTEPP'), was launched in 2008 in Tai Lake Basin of Jiangsu Province. Under this program, a cap is placed on the total COD allowed for discharge. Firms must purchase a permit. The permit allowance is based on their past EIA statistics, past COD discharge amount, and other data showing the firm's pollution status, and by the water environmental capacity and the total control quantity of the region in which the program operates. If a firm cannot get a permit or the quota it is allocated is not enough, it cannot start new projects or must purchase a permit from another enterprise. CUTEPP aims to explore the possibility of water pollution control through a market-based mechanism at a water basin scale in China.
} 
target of the total discharge of major water pollutants, the environmental protection department of the people's government at or above the county level have power to order it to treat the water within a prescribed time limit and impose a fine on such entity amounting to a minimum of two times but less than five times the amount of the pollutant discharge fee payable.

The second paragraph of art 74 further authorises the environmental protection authority to properly supervise and enforce needed action, such as curbing production or discharge, or by ordering the suspension of production activities pending rectification of the problem within a prescribed time limit (generally within one year) or a further order to close down operations will follow.

\section{Increased number of enforcement mechanisms and penalties}

LPCWP 1996 has been criticized for having weak enforcement mechanisms. ${ }^{22}$ LPCWP 2008 addresses some of the criticisms. Article 75 empowers the relevant environmental protection department to order violators, such as those who set up illicit sewage outlets or install covered conduits, to dismantle such facilities within a prescribed time limit and pay a fine ranging from RMB 20000 yuan to 100000 yuan.

The provision of this type of empowerment to an authority is rare in the Chinese environmental law regime.

In the case of the illicit installation of covered conduits or other serious acts, the responsible environmental protection department shall propose to the people's government at or above the county level that an order be given to the entity to suspend its production activities pending rectification of the illicit installation.

Where water contamination occurs - such as through the discharge of oil, acidic, viscous or alkaline solutions into a water body - or there is discharge of deadly toxic liquid waste into a water body, the environmental protection department has the power to appoint an entity or institution to take charge of cleaning up the contamination. Article 76 directs that the entity responsible for the polluting activity must pay the clean-up costs. Article 83 also provides the power to order a clean-up of water pollution incidents.

Penalties, especially fines, are the main instrument of enforcement in LPCWP. Previously, the imposition of fines was limited to the polluting entity or institutions. LPCWP 2008, however, extends the imposition of fines to individuals. Article 83 directs that where an entity or institution is in violation of the law which resulted in a water pollution accident, those with direct responsibility shall be fined an amount up to a maximum of 50 per cent of income gained from the entity in the immediately preceding year.

Moreover, LPCWP 2008 increases the applicable scope of the administrative penalty. Compared with LPCWP 1998, LPCWP 2008 adds six 'wrongful behaviours' (arts 74 and 75). They are failure to:

1. Install automatic monitoring equipment for water pollutants discharge,

2. Supervise monitoring equipment as required by law to ensure the equipment's effective operation,

3. Self monitor industrial waste water discharge;

4. Retain original monitoring records (art 72(2)(3)); and

5. Maintain discharges of water pollutants below the provisional standards or control targets of the total discharge of major water pollutants (art 74).

\footnotetext{
${ }^{22}$ C F Wang and J Feng, 'New Development of Legislation on Preventing and Controlling Water Pollution in China' (2009) 8 Journal of Beijing Forestry University.
} 
As well, art 75 counts as a 'wrongful behaviour' the installation of covered conduits for waste water discharge.

\section{Increasing polluters' costs for violation of the law}

If the cost of compliance is greater than that the cost (either monetary or personal) of violation of the law, a 'rational' manager may choose to violate the law. As already noted, this was the case in China with regard to water law. An objective of LPCWP 2008 is to overcome this 'irrational' situation. The law introduces a number of improvements to redress the imbalance in the cost of violation.

The first improvement is an increase in the administrative fine. A 100 million yuan ceiling to the administrative fine that applied to a water pollution accident ${ }^{23}$ assessed as 'gravely serious' or 'exceptionally serious' has been replaced in LPCWP 2008 with a fine that may be up to 30 per cent of the direct loss caused by the water pollution accident. 'Comparatively serious' pollution incidents may attract a fine amounting to 20 per cent of direct losses caused by the incident (art 83).

The second improvement to LPCWP 1996 that the 2008 amendments made was to enable the imposition of an administrative fine of between half million to one million yuan to an expanded range of violating conducts. The entire period in which the entities carried out the violating activity must be considered when determining the amount of the administrative fine. For example, LPCWP 2008 imposes a fine amounting to a range of three to five times the discharge fee that ought to have been collected for the whole period in which the illicit discharge occurred (art 74); and a fine of one to three times the discharge fee for unlawful conduct has to be applied if an entity stops using a water pollutant treatment facility, or dismantles or lays idle such facilities (art 73). Therefore, the longer the entity pollutes water in violation of permitted amounts, the greater the fine.

A further improvement to the law made by LPCWP 2008 is that, apart from the use of a higher administrative fine, authorities can use other administrative penalties such as ordering a cessation of the illicit conduct, suspension of business operations and even closing down the offending entity.

\section{More rules for citizens to access the justice}

Increased water pollution incidents and accidents are the cause of many environmental disputes and lawsuits concerning citizens' health or property damages. In general, Chinese environmental law adopts the doctrine of strict liability in pollution torts. However, for a long time, the absence of specific rules, such as rules pertaining to causality, the burden of proof and the measuring of pollution-affected damages, hindered the people's courts in using this doctrine. ${ }^{24}$

LPCWP 2008 has made legislative progress in this area. Article 87 stipulates that, in a lawsuit for compensation for damages caused by water pollution, polluters bear the burden of proof in those instances where the causality between their conduct and the damages is in dispute (art 85). ${ }^{25}$

\footnotetext{
23 PetroChina, the nation's largest oil producer, was fined 1 million yuan, out of a net income of 133 billion yuan in 2005 , for the accident that affected the drinking water of three million people. That contrasts with the US\$20 billion that President Barack Obama has demanded from BP for the worst oil spill in United States history.

${ }^{24}$ There were some important rulings but, in general, the system was ineffective. Two important judicial interpretations are especially relevant. The first is The Opinions of the Supreme People's Court on Several Issues of the Application of Civil Procedure Law, which came into effect on 14 July 1992. It adopted a reversion of the burden of proof to the inflictor in order to implement strict liability in environmental pollution torts litigation. The second is The Several Provisions of the Supreme People's Court Concerning the Proof of Civil Lawsuit, which took effect on 1 April 2002 to address not only the reversed burden of proof but also to explicitly address the deductive causality doctrine, described as 'no existence of causality of conduct and damage' in environmental pollution torts cases.

${ }^{25}$ These instances are defined in art 85 of LPCWP 2008 as follows: 'In the instance of force majeure, or that victims on purpose conduct water pollution, the polluter is free from liability for damages to victims; and in the instance that third parties cause water pollution, the polluter first bears liability but can then revert to the third party for the lia-
} 
Under art 88(1) and (2) of LPCWP 2008, representative lawsuits are recognised. The environmental protection departments and relevant social groups may join in a collective suit for civil damage (the law also urges the government to encourage legal service professionals and lawyers to provide legal assistance to aggrieved parties (art 88(3)). Although a step forward, these measures have not fulfilled public expectations. Critics argue that the law should be more innovative, giving certain social groups or public authorities a legal standing in public litigation for the sake of the water environment that is not dependent on human loss that resulted from pollution acts.

\section{Torts liability Law}

On 26 December 2009, the Peoples Republic of China Tort Liability Law ('TLL') '26 was released by the Standing Committee of the National People's Congress after eight years of discussion and debate. This Law formally entered into force on 1 July 2010. It serves as a separate ordinance of equal importance with another civil rights law, the Peoples Republic of China Property Law, which passed in 2007. These laws constitute China's civil code.

TLL 2009 presents a significant change to the civil law's position with respect to liability for environmental pollution by formally adopting strict liability. As commonly known worldwide, the remedy doctrine concerning pollution torts, including water pollution torts, is strict liability, whereby the violation of law or the subjective fault of the polluter is ignored as a fact of causality. However, the adoption of strict liability in Chinese environmental legislation has varied from the inception of the Environmental Protection Law (EPL, Interim) $1979^{27}$ in which fault liability was effective, up to the present time. LPCWP 1984 was the first environmental law to address the doctrine of relative strict liability regardless of narrower water pollution torts. This soon contradicted the basic civil law, the General Rules of Civil Law ('GRCL') $1986,{ }^{28}$ which recognized fault liability for all torts. ${ }^{29}$ GRCL 1986 stated that any person who polluted the environment and caused damage to others in violation of state provisions for environmental protection and the prevention of pollution, had to bear civil liability in accordance with the law. This meant that a person could be liable for environment pollution only when he/she violates the relevant law. Since then, although LPCWP 1996 and 2008 - and even interpretations of the Supreme People's Court ('SPC'), have addressed the application of a strict liability doctrine, the contradiction between civil law and environmental law has provided the courts with the legislative loopholes for not to applying the strict liability doctrine because of the concern that its application would favour victims but hinder economic growth.

TLL 2009 redresses the situation by stating that polluters are assumed to take liability for the loss and injury caused by their pollution activities, irrespective of whether they act against the relevant environmental law or not. Along with the recognition of strict liability doctrine, TLL 2009 clarifies the burden of proof is on polluters. It is a polluter's sole responsibility to defend himself by showing that he is not legally liable, and that there is no causative connection between his conduct and the harm caused to the victim. Joint liability is clarified in TLL 2009; if the environmental pollution is due to a third party's fault, the victim may seek relief and compensation either from the polluter or the third party. The polluter can pursue the responsible third party for compensation once it has compensated the victims for the damages incurred.

bility; and in the instance that the victim causes water pollution due to significant negligence, the polluter can mitigate the liability for damages'.

26 Torts Liability Law 2009, National People's congress, Order No 21, 26 December 2009 <http://ww.gov.cn/flfg/200912/26/content 1498435.htm>.

${ }^{27}$ Environmental Protection law (Interim) or People's Republic of China 1979, The Standing Committee of National People's Congress, Order No 2, 13 September 1979

<http://www.hflib.gov.cn/law/lawfalvfagui2/jjf/flfg/NL\%20ZRZY\%20HJBH/1152.htm>.

${ }^{28}$ General Rules of Civil Law of the People's Republic of China, National People's Congress, Order No 37, 12 April 1986 <http://www.ahga.gov.cn/government/fagui/mf1/low_view1.htm>.

${ }^{29}$ Article 124 of the GRCL 1986 states, "Any person who pollutes the environment and causes damage to others in violation of state provisions for environmental protection and the prevention of pollution shall bear civil liability in accordance with the law'. 
Because TLL 2009 has not been in effect for long, its effectiveness is not yet known, but the public has great expectations for more judicial favour to victims. ${ }^{30}$

\section{Policy initiative to address pollution liability}

As mentioned in the introduction of this paper, many people assume that China is entering a period with an increasing frequency of environmental pollution incidents. To respond to this situation and strengthen the implementation of newly developed legislation against water pollution, two policies are notable: the pilot program of environmental pollution liability insurance; and the administrative compensation requirements in regions for exceeding pollution targets.

\section{Environmental pollution liability insurance}

In most water pollution accidents, damage to human health and property are difficult to compensate. The entities responsible for the pollution accidents usually only pay part of the remedy to victims, and governments and society bear most of the losses caused by the pollution. In order to ensure that victims receive proper and timely compensation in the event of unintended and sudden pollution accidents, Chinese governments are introducing market instruments to divert the risk of the management of water pollution incidents to other concerned parties. In February 2008, SEPA and the country's insurance regulatory commission jointly launched the environmental pollution liability insurance scheme by issuing the policy, Guiding Opinions. This policy effectively set a roadmap for establishing an environmental pollution liability insurance system in China. ${ }^{31}$

The development of the environmental pollution liability insurance system is being implemented in two steps: first, to carry out pilot projects in major industries and areas, and develop a list of enterprises and facilities (in major sectors) that buy insurance on the basis of the rate of environmental risks as well as the pollution damage compensation standards - this pilot project began in $2009 ;{ }^{32}$ second, by 2015 , to promote the system all over the country, and basically improve the various mechanisms for risk assessment, loss assessment, identification of liability, handling of the accidents and compensation.

The obstacles to promoting pollution liability insurance have become apparent during the pilot stage. Very few entities voluntarily engaged in the scheme because of: a lack of awareness of risk management; insurance premiums were high compared with other insurances; and enforcement of polluting behaviour in violation of the law was not stringent. Clearly, regulatory authorities need to develop good governance for the insurance industry to be able to operate. The pilot project also showed that technical issues, such as type of environmental liability insurance products, the scope of the liability and the rate of insurance premiums according to different kinds of products, needs to be resolved. More importantly, in the early stage of developing pollution liability insurance, some adverse impacts of the system need to be considered and avoided, for example the entities may take advantage of having insurance to discharge pollutants. ${ }^{33}$

\footnotetext{
${ }^{30} \mathrm{Q}$ Du, 'The People's Republic of China' in L Kotze, and A Paterson (eds), The role of the Judiciary in Environmental governance: Comparative Perspectives (Wolters Kluwer, 2009) 114.

${ }^{31}$ The first case of environmental pollution insurance occurred in Hunan Province in September 2008. Zhuzhou Farm Chemical Company caused pollution to farmers. The Ping An Insurance Company that the polluter contracted compensated victim farmers. See the news report at <http://hunan.voc.com.cn/article/200812/200812040926067210.html>.

32 In 2009, these two departments jointly conducted pilot projects on environmental pollution liability insurance in enterprises: that produce, operate, store, transport and use hazardous chemicals; petrochemical enterprises and hazardous waste disposal enterprises that might likely have pollutant accidents; and, especially, enterprises and sectors that have suffered from major pollution accidents in recent years. See MEP, 'Local Practice on Environment Pollution Liability Insurance’ (2010) 8 The Journal of Environmental Protection 25.

${ }^{33} \mathrm{~L} \mathrm{Pi}$, 'Green Insurance: Status, Issues and Suggestions' (2010) 16 China Insurance 3.
} 


\section{Administrative compensation mechanism for target-exceeded pollutants discharge}

As already noted, the stipulation in LPCWP 2008 of the total discharge control of major pollutants is an important technical instrument to accommodate other legally binding liability and obligations. For example, if total discharge controls of major pollutants fail in a region, the leader of the local government and the environmental protection department can be accused of being incompetent and removed from office. Or, alternatively, instead of political sanctions, administrative obligations may be imposed, such as the administrative compensation system imposed in Jiangsu Province, for water quality control of the Tai Lake basin.

In the Tai Lake case, there was a massive outbreak of blue-green algae in spite of efforts over many years to cut pollution discharges into the lake. One such outbreak in 2007 disrupted water supplies to the one million residents of Wuxi City. Since in 2007, Jiangsu Province has implemented an environmental compensation scheme based on the total allowable discharge level of major pollutants within the river basin. ${ }^{34}$ The scheme stipulates that cities in the upper reaches of the basin must monetarily compensate those in the lower reaches if their pollutant discharges exceed the standards. In the first round of compensation at the end of 2008, the provincial capital city, Nanjing, paid 18000 yuan ( $\$ 2600$ ) to the city of Changzhou, which in turn paid the same amount to Wuxi City on the lower reaches of the Tai Lake. ${ }^{35}$ Since March 2009, Jiangsu Province government has extended this environment compensation scheme to another five cities in the Tai Lake basin ${ }^{36}$. Collected payments are used for treatment of the water environment in the Tai Lake basin.

\section{Future challenges in effective compliance and enforcement of water law}

There are great hopes that the revised LPCWP 2008 and relevant policies will lead to better management of the conflicts that arise from the tension between more economic development, and greater protection of the environment and human health. ${ }^{37}$ But, as is well understood, the resolution of water pollution conflict does not only depend on 'good' law or even on 'strict' law, but also on effective compliance and enforcement of the law.

As a part of its implementation plan for LPCWP 2008, MEP investigated the operation of almost a million Chinese companies in 2008, ordering more than 2000 of the investigated companies to suspend or curb production. ${ }^{38}$ Between March and May 2010, MEP started a nationwide investigation of drinking water and mine tailing ponds, monitoring paper mills and water treatment companies in provinces, including Guangdong and Hebei. MEP found that as many as half did not comply with the law. As a result, to strengthen compliance and enforcement, MEP has set up a database of violators and encouraged residents to report complaints.

\footnotetext{
${ }^{34}$ The policy documents are the Provisions on Regional Compensation of Environmental Resources in Jiangsu Province and the pilot Program for Regional Compensation of Environmental Resources in Jiangsu Tai Lake Basin, issued in 2007 by the People's Government of Jiangsu Province.

35 Y Wan, 'Joint Efforts against Water Pollution' China Daily, 10 March 2010.

${ }^{36}$ Pollutants discharged at higher than legal limits include: chemical oxygen demand of sewage, 15000 yuan per ton; ammonia nitrogen and phosphorus at 100000 yuan per ton.

${ }^{37}$ T Bie, 'Analysis on the Progress of the New Law for the Prevention and Control of Water Pollution' (2008) 3 Environmental Protection 40.

${ }^{38}$ Since April 2008, MEP has conducted an investigation on environmental risk of chemical and petroleum enterprises located along key rivers and their tributaries, and of protected areas or upper reaches of drinking water supplies. As a result of the investigation, construction projects in these areas taking place without environmental impact assessments or without facilities for preventing and controlling environmentally adverse impacts were ordered to suspend production. A national information system for environmental risk and chemicals of key industries was set up. See 'MEP conducting environmental risk checking to chemical enterprises along key rivers', China Securities Journal, 31 August 2008. For the ongoing process of MEP's environmental risk checking and information system building, see <http://yjb.mep.gov.cn/yj/>.
} 
In spite of such measures, the number of environmental accidents continued to rise; 102 in the first half of 2010 compared with 171 for the whole of 2009. ${ }^{39}$

The accident of Zijin Mining Croup Co's acid leak to Ting River in July 2010 provides an appropriate case study for examining the ongoing legal challenges China faces in terms of dealing with water pollution and conflicts.

\section{The case of Zijin acid leaks to Ting River}

On 23 June 2010, fish farmers on the lower reaches of the Ting River reported fish deaths to the local government, suspecting that the cause was pollution. Two days later, environmental protection, aquatic production and epidemic prevention experts from Fujian Province confirmed that the fish deaths were caused by water pollution. Zijin Mining Croup Co Ltd (hereafter Zijin) was found to have released a total of 9100 cubic meters of acid into the Ting River on 3 and 16 July. The result was massive kills of aquatic life in the Shanghang and Yongding counties on which more 72000 residents depend. As a result, on 8 October 2010, the Bureau of Environment Protection of the Government of Fujian Province fined Zijin 9.56 million yuan ( $\$ 1.43$ million) and ordered the company to take remedial action. Zijin agreed to undertake the required action and undertake measures to prevent future contaminations. ${ }^{40}$

\section{An unintended accident?}

Detailed investigation found a long history of illegal action by Zijin and authorities:

- In July 2007, following an investigation into Zijin operations, SEPA issued an official letter to the Securities and Futures Regulatory Commission to urge the Commission to intensify the environmental supervision on Zijin.

- In September 2009, the environmental protection department of Fujiang Province found Zijin discharged waste into Ting River that exceeded the legal discharge standards. The department ordered Zijin to correct and treat wastes in a timely manner. This order was not complied with or enforced.

- In May 2010, in its Surveillance Report of the Environmental Check on Stock Companies, MEP, ${ }^{41}$ listed Zijin as the worst of 11 stock companies ordered to take corrective action to limit environmental risks from their plant within a specified time.

- Fish deaths were reported in the Ting River in early June 2010 and the local educational department issued a public notice to warn children and teenagers not to eat local fish.

The official report ${ }^{42}$ into the cause of Zijin acid leak in July 2010, noted that there had been three major causes for the incident:

1. The isolating film for wastewater storage had cracked which led to acid leaking into the river (experts pointed out that the design and engineering of the isolating film had been a problem).

2. Zijin illegally connected the deposit observation well to the flood discharge well, thereby directly introducing acid into to river. This illegal connection was discovered in 2009 by the provincial environmental protection department and an order was issued to uncouple the wells. Zijin failed to comply.

3. The self-monitoring facility was broken.

Clearly, the Zijin accident was hardly unintended or sudden, but the consequence of long-term and continuous intended violations.

\footnotetext{
39 'China's Environmental Accidents Double on Growth Toll', Bloomberg News, 28 July 2010.

${ }^{40}$ Z-Z LAN, ‘Messing Up and Fessing Up’ Beijing Review, October 2010.

${ }^{41}$ MEP Paper No 67, 2010.

${ }^{42}$ The Bureau of Environment Protection of the Government of Fujian Province publicized the report of causes of the Zijin mining pollution accident on 16 July 2010 on its official website.
} 
Zijin publicised the toxic leaking accident to the stock market on 12 July 2010, nine days after the first leakage. This violated the information disclosure requirements of Securities Law, ${ }^{43}$ Company Law, ${ }^{44}$ Environmental Information Disclosure Provisions and Criminal Law ${ }^{45}$ for stock companies.

Ironically Zijin won the award of 'China's Best Faith Enterprise in 2010'.

Notably, the local government and environmental protection watch dog did not effectively excise their responsibilities, placing a higher priority on local economic growth and official relationships than proper supervision of enterprises. ${ }^{46}$ This negligence made local government officials also culpable.

It may have been more appropriate to remove officials and apply sanctions earlier rather than wait until the pollution incidents had become critical. ${ }^{47}$

\section{High penalties?}

Zijin was fined almost 10 million yuan - the highest fine recorded in the history of environmental pollution control. Some have hailed this outcome as a victory for LPCWP 2008, but the most environmental specialists remain sceptical, arguing that the sanctions applied to Zijin should have had an effect on its stocks. Instead Zijin Mining Group Co Ltd stock prices did not decrease after the fine was imposed on 8 October 2010 because investors had expected a much higher fine. According to a report by China Asset Management Co Ltd, the direct economic losses to the company as a result of the pollution incident were only 31.87 million yuan ( $\$ 4.78$ million). Altogether, the incident cost Zijin little more than 41 million yuan $(\$ 6.15$ million). For a company that, in the first half of 2010 , generated 13.46 billion yuan ( $\$ 2.02$ billion) in business revenue and 2.7 billion yuan ( $\$ 404.8$ million) in net profits and whose total assets are 29.65 billion yuan ( $\$ 4.45$ billion), the total cost of the incident had little to no impact on operations. ${ }^{48}$

Critics argue that the fine - 30 per cent of the direct cost of pollution under LPCWP 2008 - is vague and not sufficient to deter violating conducts. The company's long-term violation behaviour and economic gains from violations remain unaccounted for by this penalty. In addition, 'direct loss' lacks technical explanation and practical rules, easily generating disputes and conflicts.

\section{Who compensates the victims?}

With regard to losses incurred by the victims of water pollution, local governments compensate 'direct losses' of affected fishing households by buying the dead fish based on market prices. However, 'indirect losses', such as loss of fish stocks and viability of other aquatic businesses and even loss of a safe drinking water supply - caused by polluted water bodies remain unaccounted for in LPCWP 2008.

\footnotetext{
${ }^{43}$ The Securities Law of People Republic of China 2005, amendment of the 1998 version, The Standing Committee of National People's Congress, Order No 43, 27 October 2005 <http://www.gov.cn.flfg/2005-10/28/content 85556.htm>.

${ }^{44}$ The Company Law of People's Repulbic of China 2005, revised from the amended version 2004, The Standing Committee of National People's Congress, Order No 42, 27 October 2005, see the Chinese text at http://www.gov.cn/flfg/2005-10/28/

${ }^{45}$ Environmental Information Disclosure Provisions, MEP, Decree No. 35, 11 April 2007. See the Chinese text at <http://www.gov.cn/flfg/2007-04/20/content_589673.htm>; Criminal Law of People's Republic of China 1997, National People's Congress, Order 87, 14 March 1997, National People's Congress.

${ }^{46}$ Chen Qiang, 'Zijin Mining Pollution Accident: Natural Disaster or Man-made Catastrophe?' China Youth Daily, $21^{\text {st }}$ July 2010.

${ }^{47}$ Several officials have been removed from their posts, including the Shanghang County head, Qiu Heqing, the deputy Shanghang County head, Lan Fuyan, the Director of the Shanghang County Environmental Protection Bureau, Chen Jun'an, and the Director of the Longyan City Environmental Protection Bureau, Lin Lianjin. See MEP proposed resolutions to solve Zijin Mining Pollution Accident, <http://news.xinhuanet.com/society/2010-07/16/c_111961797_2.htm>.

${ }^{48}$ Lan, above $\mathrm{n} 35$.
} 


\section{Future perspectives}

In conclusion, developments over recent years in China's national law and policy concerning water pollution have responded to some key issues of social conflict caused by water pollution, government accountability, entities' liability and citizen's rights. Nevertheless, challenges remain, with the main challenge being a need to strengthen compliance and enforcement.

On the positive side, China has dedicated efforts in this arena, not just in legal and policy areas, but also politically. Since 2004, the Chinese central government has called for an increase in social harmony. ${ }^{49} \mathrm{~A}$ society in harmony is one of stability and unity, where people are assured of their basic needs for food, health and liberty. The urge to build China into a society in harmony has become a strong political commitment to support the rule of law in combating various types of civil conflicts - among which resolving water pollution conflict is central.

Keywords: China water law, China water pollution law, the case of Zijin, compliance and enforcement of law

\footnotetext{
${ }^{49}$ Decision of the CPC Central Committee on Strengthening the Party's Ruling Ability Construction. This issue was discussed and passed in the fourth plenary session of CPC $16^{\text {th }}$ central commission on 19 September 2004. This decision is the first that significantly put forward and explained the scientific topic of building socialist harmonious society as one of five missions for strengthening the Party's ruling ability construction before the whole Party.
} 